\title{
Currarino Syndrome (SC): A case at the University Hospital of Mother and Child Lagune Cotonou
}

\author{
Gbenou A.S. ${ }^{1 *}$, Akodjenou J. ${ }^{2}$ Seidou F. ${ }^{3}$, Adeoti F. ${ }^{1}$, Fiogbe M.A. ${ }^{4}$, Akpo-Akélé M.Th ${ }^{3}$ and Bankole R \\ ${ }^{1}$ Pediatric Surgery Department, University Hospital of Mother and Child Lagune Cotonou (Benin) \\ ${ }^{2}$ Anesthesia and Resuscitation Department, University Hospital of Mother and Child Lagune Cotonou \\ ${ }^{3}$ University Training and Research Unit in Pathological Anatomy Health Sciences Faculty Cotonou. \\ ${ }^{4}$ University Clinic of Pediatric Surgery, National University Hospital CNHU-HKM of Cotonou. \\ ${ }^{5}$ Pediatric Surgery Department, University Hospital Treichville Abidjan (Ivory Coast)
}

* Corresponding Author: Gbenou Antoine Séraphin, Ph.D, Associate Professor, Pediatric Surgery Department, University Hospital of Mother and Child Lagune Cotonou Benin. seraphin_gbenou@yahoo.fr

Received Date September 18, 2020; Accepted Date: March 05, 2021; Published Date: March 22,2021

Citation: Gbenou A.S., Akodjenou J., Seidou F., Adeoti F., Fiogbe M.A., Akpo-Akélé M.Th. and Bankole R. (2021) Currarino Syndrome (SC): A case at the University Hospital of Mother and Child Lagune Cotonou. J Surgical Case Reports and Images, 4(2): DOI: 10.31579/2690-1897/048

Copyright: (C2021 Gbenou Antoine Séraphin. This is an open-access article distributed under the terms of the Creative Commons Attribution License, which permits unrestricted use, distribution, and reproduction in any medium, provided the original author and source are credited.

\begin{abstract}
Introduction: The Currarino syndrome (CS) is one of the rare syndromic forms of anorectal malformations (ARM).

Observation: This is the clinical case of a 3 days male newborn admitted for high ARM in the pediatric surgery Department of the Lagune Mother and Child University Hospital of Cotonou. An emergency colostomy was performed. At the age of 7 months as a prelude to anorectoplasty, the distal colography revealed a semilunar pelvic opacity in front of the sacrum. The posterior sagittal approach according to Peña could not reveal the distal end of the intestine. The reconstruction of the sphincter-muscular complex was done on a tracheal tube. The abdominal approach allowed the discovery and resection of a presacral mass. The rectal pouch end found was then lowered. Post-operative follows up was uneventful. The standard postoperative X-ray revealed a partial agenesis of the sacrum. The histology of the operative specimen found a cystic lipoma. The diagnosis of CS was done. The search of a HLXB9 mutation was not possible.

Conclusion: The clinical observation associated with standard radiological investigations highlighted the triad: anorectal malformation, presacral tumor, and partial agenesis of the sacrum, which upheld the diagnosis of CS; but the search for an indispensable HLXB9 mutation was lacking for the genetic link
\end{abstract}

Key words: anorectal malformation, currarino syndrome, child

\section{Introduction}

The Currarino's syndrome (CS) is one of the rare syndromic forms of anorectal malformations (ARM). It is a hereditary disease with autosomal dominant transmission [1, 2,]. Described by Currarino in 1981, this syndrome is characterized by a triad associating anorectal malformation, a defect in the sacrococcygeal region and a presacral mass (meningocele and/or teratoma, neurenteric cyst) [2, 3 and 4]. It often notice in affected patients severe constipation and Mullerian duplication as two other signs of the Currarino sequence [2, 5 and 6]. There may be communication with the meninges; affected patients are therefore at risk of purulent meningitis $[7,8]$. The diagnosis can sometimes be difficult, remaining suspected until surgery $[6,9]$.

We report a case of this syndrome that was managed in our department.

\section{Observation}

The patient was a boy admitted on the third day of life for acute intestinal obstruction on ARM. The clinical examination showed the absence of anal orifice. There was no sign of meconuria or perineal fistula. An emergency double barrel rifle colostomy (Figure 1) was performed with an uneventful follow up and the child was discharged. At 7 months of age, as part of the paraclinical explorations for anorectoplasty, a distal colostogram (Figure 2) performed, revealed a semi-lunar image veiling the sacrum and making a presumptive mass effect on the rectal pouch end. Pelvic CT and MRI were not performed due to lack of financial means.

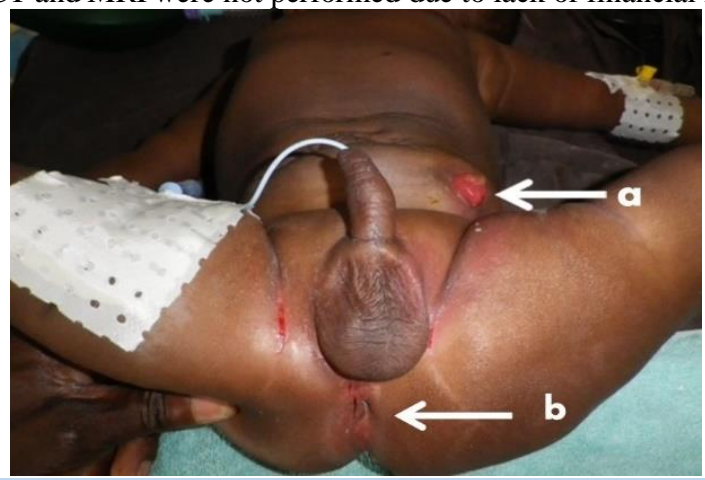

Figure 1. Anorectal malformation without fistula (a: colostomy. b: presumed area of the anus) 


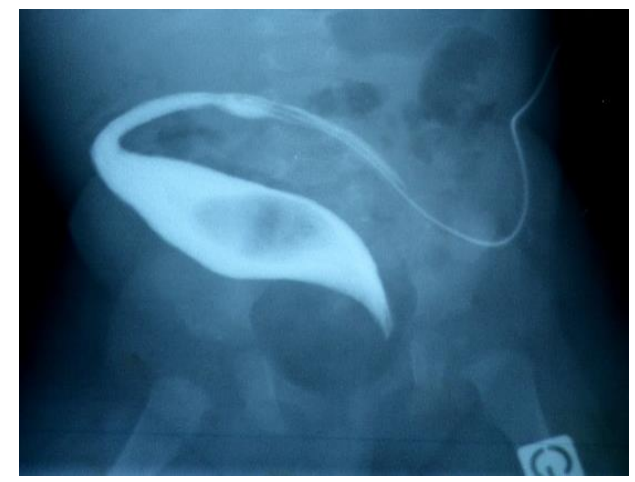

Figure 2. Distal colography showing the imprint of the mass on the rectal pouch end.

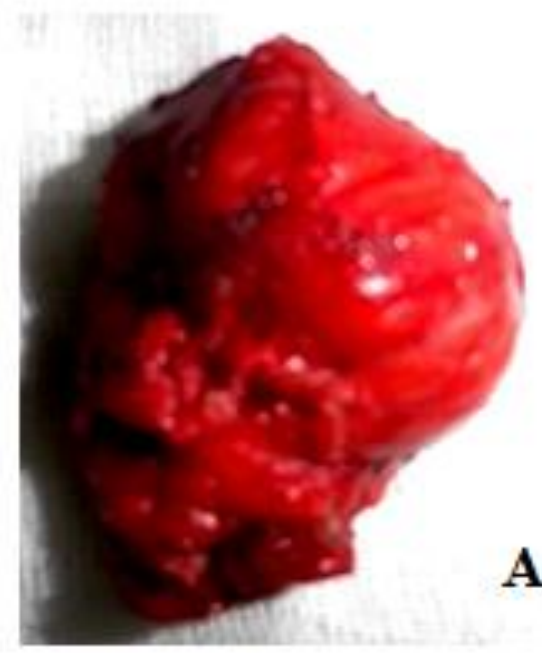

During posterior sagittal anorectoplasty (PSARP) using Peña technique, the rectal pouch end, could not be exposed. Which brought us to do, a reconstruction of the sphincter muscular complex on a tracheal tube. A complementary abdominal approach was performed and permitted the discovery and resection of a presacral mass (Figure 3 ). The rectal pouch end found was then lowered using the tracheal tube as a tutor [10]. Restoration of colonic continuity was performed at the same time to allow sufficient colonic length for the lowering. After the PSARP, the perineum was put to rest without tension on the sutures, by placing a plaster at the level of the two joined legs. Anal dilatation started as soon as the perineal surgical wound was healed on the $21^{\text {st }}$ day and was performed using Hégar dilatator. The dilatation sessions were, among other things, a training in defecation. Expulsion of the lubricated dilatator introduced into the anal canal, was made possible by the contractile force of the musculosphincteric complex. The immediate post-operative follows up was simple.

Figure 3. Presacral resected Tumor.

$\mathrm{a}=$ resected tumor, $\mathrm{b}=$ resected open tumor

Histopathological examination of the resected tumor, found a cystic lipoma. Post-operative pelvic x-ray revealed a partial agenesis of the sacrum (Figure 4). The CS diagnosis was upheld. The search for a

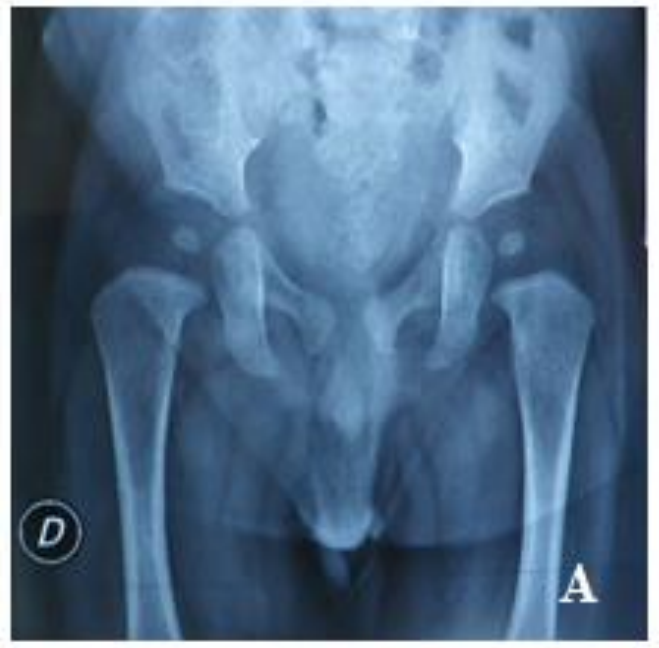

mutation of the HLXB9 gene was not realised. Reviewed at 36 months postoperatively, the clinical examination was normal. A pelvic X-ray performed to the mother was normal.

\footnotetext{
Figure 4. Partial agenesis of the sacrum indicated by the arrow $(\mathrm{a}=$ frontal $\mathrm{X}$-rays; $\mathrm{b}=$ profile $\mathrm{X}$-rays)
} 


\section{Discussion}

Since the first reported case of CS, just over 300 other cases have been diagnosed [11] at a rate of one case per 100000 people [12]. It belongs to the group of neurenteral malformations $[1,2]$. It results from an abnormal separation between the neuro-ectoderm and the endoderm. This syndrome is the only form of sacral agenesis currently known [3]. Martuciello et al [4] defined 3 types of CS namely: the complete form with the presence of the hemisacrum, the ARM, and the presacral mass; a mild form with the presence of a hemisacrum and of one of the other anomalies, and a minimal form with the presence of a hemisacrum only. The case described in our observation, with the presence of a hemisacrum, the ARM and the presacral mass is a complete form of CS.

The deformation of the sacrum known in the CS under of the "scimitar" sign is often demonstrated on X-rays from conventional radiography during manifestations of complications related to the polymal formative complex. [13, 14]. According to Kumar et al [9], because of the scarcity and the varied forms of CS, there is still a high probability of misdiagnosis in the initial management of ARMs.

With regards to the presacral mass, most cases were pre-surgery discoveries [6, 9, 13 and 14] or occurrence of post-surgery complications of the ARM such as constipation.

By its nature the presacral mass may consist of a teratoma, harmatome, neuroenteric cyst, anterior meningocele or their combination [11]. Nowadays, the appropriate image-based examination for the preoperative detection of the presacral mass and an assessment of its nature is the MRI [6, 8 and 13]. Ultrasound could be a good remedy in some cases [13].

In our context MRI is only available in the private sector and the financial cost is beyond the means available to the parents; the ultrasound was not performed. The only presumptive diagnostic element was the semilunar image veiling the sacrum which suggested a presumptive mass effect on the rectal end pouch at the distal colostogram.

In our case, the anatomopathological examination of the resected mass concluded with a cystic lipoma, which explains the variability of the histological nature of this mass [2,3].

The forms of ARM described in the CS are often recto-urinary fistula, rectal atresia, anal stenosis that in many cases simulate a HD $[9,11,13$ and 14]. Furthermore, it was a high ARM with a distal portion that was not accessible by the posterior sagittal approach, which is nevertheless recommended in case of total resection of the mass and anorectoplasty [8, 15]. In our case, this posterior approach was used only for the reconstruction of the perineal tract and to lowered the distal intestine as in the case of some high ARM. The complementary abdominal approach in our case allowed the resection of the presacral mass and the displacement of the rectal pouch as well as its lowering.

According to Samuel et al [6], surgical treatment must be personalized considering the risk factors involved. Thus, in the case where the diagnosis of the CS is certain, a multidisciplinary surgical approach is desirable in order to reduce morbidity and mortality. [11, 14].

With the CS the mode of inheritance is autosomal dominant in nearly half of the cases [16]. The homeobox gene HLXB9 which encodes a transcription factor (HB9) protein) is located in the chromosomal region 7q36. Mutations of this gene have been demonstrated in many cases of family CS and in only $30 \%$ of sporadic cases; this suggests that other genes are involved in this syndrome. [5, 16]. Genetic research in syndromic ARM is still one of the many problems affecting developing countries like Benin.

In our case we did not observe stubborn constipation in the postoperative period; the search for possible Mullerian duplication was not undertaken. Stubborn constipation and Mullerian duplication are the fourth and fifth signs of the Currarino sequence $[7,16]$ to look out for.
The lack of financial means by the parents in the case presented, and the lack of universal health insurance at national level, have been limiting factors for paraclinical investigations in imaging and genetics. Long-term medical monitoring must be appropriate.

\section{Conclusion}

Clinical observation associated with standard conventional radiological investigations has highlighted the triad: anorectal malformation, presacral tumor, and partial agenesis of the sacrum, which upheld the diagnosis of CS; but the search for an indispensable HLXB9 mutation is lacking for the genetic link.

\section{Conflicts of interest}

The authors declare no conflicts of interest regarding the publication of this paper

\section{References}

1. Belkacem S, Chellaoui M, Dafiri R. (2010) Currarino syndrome. Radiology Sheets. 50 (3): 115-120.

2. Cretolle C, Rousseau V, Lottmann H, Irtan S, Lortat-Jacob S, Alova I, Michel JL, Aigrain Y, Podevin G, Lehur PA, Sarnacki S. (2013) Anorectal malformations. Arch of Pediatrics. 20, 519-27.

3. Currarino G, Coln D, Votteler T. (1981) Triad of anorectal, sacral, and presacral abnormalities. AJR Am J Roentgenol. 137: 395-8.

4. Martucciello G, Torre M, Belloni E, Lerone M, Pini Prato A, Cama A., Jasonni V. (2004) Currarino syndrome: proposal of a diagnostic and therapeutic protocol. J Pediatr Surg. 39 (9): 130511.

5. Cretolle C, Zerah M., Jaubert F. (2006) New clinical and therapeutic perspectives in Currarino syndrome (study of 29 cases). J Pediatr Surg. 41: 126-31.

6. Samuel M, Holmes K. (2000) Currarino triad: diagnostic dilemma and combined surgical approach. J Pediatr Surg. 35: 1790-4.

7. Fleury J, Picherot G, Cretolle C. (2007) Currarino syndrome as an etiology of a neonatal Escherichia coli meningitis. J Perinatol. 27: 589-91.

8. Abouzeid AA, Mohammad SA, Abolfotoh M, Radwan AB, Ismail MM, Hassan TA. (2016) The Currarino triad: What pediatric surgeons need to know. J Pediatr Surg. 27. pII

9. Kumar B, Sinha AK, Kumar P, Kumar A. (20196) Currarino syndrome: Rare clinical variants. J Indian Assoc Pediatr Surg. 21 (4): 187-189.

10. Pena A. (1990) Atlas of surgical management of anorectal malformations. Springer Verlag New York. p 104.

11. Buyukbese Sarsu S, Parmaksiz ME, Cabalar E, Karapur A, Kaya C. (2016) A Very Rare Cause of Anal Atresia: Currarino Syndrome. J Clin Med Res. 8 (5) 420-423.: 420-423.

12. Lee JK, Towbin AJ. (2016) Currarino: Syndrome and the effect of a large anterior Sacral Meningocele on Distal Colostogram in an Anorectal Malformation. J Radiol Case Rep. 30.10 (6):16-21.

13. Idrissi ML, Babakhoya A, Bouabdellah Y, Hida M. (2011) A rectovaginal fistula within the scope of a Currarino syndrome. Pan Afr Med J. 10:51.

14. Saberi H, Habibi Z, Adhami A. (2009) Currarino's syndrome misinterpreted as Hirschsprung's disease for 17 years: a case report. Cases Journal. 2:118.

15. Otagiri N, Matsumoto Y, Yoshida Y. (2000) Posterior sagittal approach for Currarino syndrome with anterior sacral meningocele: a case report. J Pediatr Surg. 35: 1112-4.

16. Cretolle C, Pelet A, Sanlaville D. (2008) Spectrum of HLXB9 gene mutations in Currarino syndrome and genotype-phenotype correlation. Hum Mutat. 29: 903-10. 